\title{
The Use of the Matrix Model of Sustainable Development (MSD) in the Production Sector
}

Karel Macik, Theodor Beran, Sarka Findova

Czech Technical University in Prague, Faculty of Mechanical Engineering, Department of Management and Economics, Karlovo nám. 13, Praha 2. E-mail: Sarka.Findova@fs.cvut.cz.

The paper deals with the practical use of matrix model of sustainable development, the MSD (Matrix of Sustainable Development) in Industrial Management and an introduction to possible problems in implementation. The method is based on expert evaluation, the output of the relational matrix are values of importance, resp. the overview of the priorities of the problem, i.e. the individual social requirements and the factors of quality products. The implementation of the MSD model contributes to the holistic understanding of the product's life cycle. The results reveal the model on the one hand in it is the real importance, and, on the other hand, the possible shortcomings of some hitherto unknown factors. The benefit is also involved in research in the field of quality management and a focus on customer requirements.

Key words: sustainable development, relational matrix, social requirements, quality factors, expert.

\section{References}

[1] BERAN, Th.; VLÁSEK, K. Analýza a hodnocení souvislostí mezi společenskými požadavky a kvalitou produktů $s$ dlouhodobým životním cyklem. Praha: ČVUT, 2010. 134 p. ISBN 978-80-01-04658-6.

[2] BERAN, Th.; VLÁSEK, K.; FLEGL, R. Expertní metoda v hodnocení procesů ISM strojírenského výrobku v jeho celoživotních etapách jako integrální část kvantifikace procesů v reprodukčním cyklu. In.: Soudobé trendy vjakosti ř́zení, XXIX, sborník semináře: Zlenice, 27. - 28. 3. 2009, ISQ PRAHA, 2009, ISBN 978-80-7265-145-0.

[3] BORKOWSKI, S.; STASIAK-BETLEJEWSKA, R.; NÁPRSTKOVÁ, N. The Kaizen philosophy in the aluminium products improvement. In.: Manufacturing Technology, Ústí nad Labem: UJEP, 2011, vol. 11, No. 11, p. 2 -5 , ISSN 1213-2489.

[4] KLÖPFER, W.; GRAHL, B. Life Cycle Assessment (LCA). Wiley - VCH; 1 edition (May 27, 2014), 440 p., ISBN13: 978-3527329861.

[5] KVAPIL, T.; POHORALÝ, M. Total Quality Management (TQM), Strojírenská technologie, X, 06/2005, No2, p. 25-29, ISSN 1211-4162.

[6] SARJA, A. Integrated Life Cycle Design of Structures. London: Spon Press, 2002, ISBN-13: 978-0415252355.

[7] SARJA, A. Reliability principles, methodology and methods for lifetime design, In: Materials and Structures/Materiaux et Constructions, Springer Netherlands, volume 43, issue 1-2, January 2010, p. 261-271, ISSN 1359-5997.

[8] SARJA, A. Structural Engineering International, Journal of the International Association for Bridge and Structural Engineering (IABSE), Int. Assoc. for Bridge and Structural Eng. Eth-Honggerberg, Volume 25, Number 2, January 2003, p. 269-269, ISSN 1016-8664.

[9] TILMAN, A., M. Significance of Decision-Making for LCA Methodology, In: Environmental Impact Assessment, Rewiev 20, Elsevier, p. 113-123. ISSN 0195-9255.

[10] ULEWICZ, R., Practical Application of Quality Tools in the Cast Iron Foundry, In.: Manufacturing Technology, Ústí nad Labem: UJEP, 2014, vol. 14, No. 11, p. 104 - 111, ISSN 1213-2489.

[11] WEIDEMA, B., P. The integration of economic and social aspect in life cycle impact assessment. In: International Journal of Life Cycle Assessment, Ecomed, 2006, vol. 11, p. 89-96, ISSN 0948-3349.

[12] WEIDEMA, B.; P., EKVAHL, T. System Boundaries and Input Data in Consequential Life Cycle Inventory Analysis. In: International Journal of Life Cycle Assessment, Ecomed, 2004, vol. 3, p. 161-171, ISSN 0948-3349. 